кафедри психодіагностики та клінічної психології

факультету психології

Київського національного університету імені Т. Г. Шевченка

http://orcid.org/0000-0003-2354-4169

DOI https://doi.org/10.35619/prap_rv.vi14.149

\title{
СЕНСОМОТОРНИЙ БАТЬКІВСЬКИЙ ОПИТУВАЛЬНИК: АДАПТАЦІЯ НА УКРАЇНСЬКІЙ ВИБІРЦ НОРМОТИПОВИХ ДІТЕЙ ТА ДІТЕЙ 3 РОЗЛАДАМИ АУТИСТИЧНОГО СПЕКТРА
}

Анотація. У статті описано та проаналізовано методику Сенсомоторний батьківський опитувальник (оригінальна назва - Sensorimotor History Questionnaire for Preschoolers). Розглядається проблема порушень обробки та інтеграції сенсорної інформащії у нормотипових дітей та дітей з розладами аутистичного спектра. Висвітлено сучасні дослідження сенсорних особливостей та порушень у дітей, звернено увагу на необхідність досліджень особливості сенсорної сфери та ї̈ порушень у нормотипових дітей та дітей з РАС (розлади аутистичного спектра, аутизм) на вітчизняній вибіриі. Описано результати адаптаџії та апробації методики Сенсомоторний батьківський опитувальник на вибіриі украӥнських дітей. Методика була переведена на украӥнську мову з мови оригіналу (англійська) із залученням професійного перекладача. Адаптований варіант пройшов асиметричний переклад, який дозволив зберегти смислове навантаження тверджень $i$ дотримання вимог чіткості та однозначності формулювань. Для підрахунку балів використовувалася програмне забезпечення Excel 2016, для перевірки психометричних характеристик методики статистична програма IBM SPSS Statistics 23. Психометричні характеристики методики показали високий та достатній рівень.

Була проведена стандартизація процедури та інтерпретаџії результатів дослідження, для иього було обчислено частотний розподіл за загальним показником та додатково - за віковими группами, для визначення меж вираженості порушень сенсорної сфери у дітей $i$ підлітків. За результатами частотного розподілу було визначено загальний розподіл балів, який дає можливість визначати наявність та вираженість порушень обробки та інтеграчії сенсорної інформачї у дітей.

Ключові слова: адаптація, апробачія, валідність, відчуття, дисфункція сенсорної інтеграції, надійність, розлади аутистичного спектра, сенсорна інтеграція, сенсорні процеси, стандартизація.

Постановка проблеми. Значна кількість дітей страждає від проблем, пов'язаних із обробкою та інтеграцією відчуттів. Дослідження показують, що від 10 до $55 \%$ школярів мають труднощі в цій галузі. Цей показник збільшується до 40-88 \% для дітей із різними діагнозами. Серед дітей з аутизмом розлади обробки сенсорної інформації досить поширені і варіюються від 42\% до 88\% (Pfeiffer et al., 2011; Pfeiffer, May-Besson, \& Bodison, 2017). Спеціалістами часто недооцінюються внутрішні ресурси дитини з аутизмом (базові структури психічної організації, такі як сенсорна інтеграція), розкриття яких робить можливою підготовку фундаменту ії цілісного розвитку. Розвинена сенсорна інтеграція забезпечує дитині ефективне функціонування у навколишньому просторі, здатність планувати власну діяльність та продуктивно взаємодіяти 3 іншими людьми (Скрипник, 2016). Дослідження особливостей обробки сенсорної інформації у дітей 3 аутизмом, адаптація зарубіжних методик та створення нового діагностичного інструментарію $є$ актуальними завданнями вітчизняної науки забезпечують можливість допомогти дітям подолати перешкоди в розвитку та адаптуватися у суспільстві. Ідентифікація труднощів, пов'язаних з обробкою та інтеграцією сенсорної інформації важлива для визначення необхідних заходів, розробки плану дій спеціалістів та батьків (Вакуленко, 2018). 
Аналіз останніх досліджень 3 проблеми. Теорія сенсорної інтеграції вперше була розроблена Ayres 3 метою зосередження уваги на неврологічній обробці сенсорної інформації. Ayres вперше описала дисфункцію сенсорної інтеграції як порушення в обробці сенсорної інформації, яка надходить 3 п’яти сенсорних аналізаторів (зір, слух, дотик, нюх, смак), а також вестибулярного апарату та пропріцептивної системи (Вакуленко, 2018). Jorquera-Cabrera, RomeroAyuso, Rodriguez-Gil, Triviño-Juárez (2017) зробили важливий вклад в дослідження сенсорних процесів у дітей, здійснивши оцінку характеристик сенсорної обробки у дітей віком від 3 до 11 років. Багатьох сучасних науковців цікавить питання порушень сенсорної інтеграції. Зокрема, вивчаються відносини між певними типами сенсорних моделей обробки інформації, складною поведінкою та захисними факторами (Dean, Little, Tomchek \& Dunn, 2018). Описується взаємозв'язок між сенсорною обробкою та ігровою діяльністю (Roberts, Stagnitti, Brown \& Bhopti, 2018); між сенсорною обробкою та порушеннями сну (К. Foitzik, \& T. Brown, 2018); між між обробкою сенсорної інформації та розвитком моторних навичок у недоношених немовлят (Celik, Elbasan, Gucuyener, Kayihan \& Huri, 2018), зв'язок між сенсорною чутливістю та віком (Ueno, Takahashi \& Oshio, 2019), проблеми сенсорної обробки та їх зв'язок із соціальними труднощами у дітей з аутизмом (Kojovic, Ben Hadid, Franchini \& Schaer, 2019), сенсорна дисфункція та їі прояви у дітей з аутизмом та у дітей без розладу аутистичного спектра (Jussila et. al. 2019), сенсорні кореляти соціальної тривоги у підлітків 3 аутизмом та нейротипових дітей (Pickard, Hirsch, Simonoff \& Happé, 2020), вплив сенсорної обробки на виконавчу та когнітивну функції у дітей 3 PAC в шкільному середовищі (Pastor-Cerezuela, Fernández-Andrés, Sanz-Cervera \& Marín-Suelves, 2020). Фактори обробки та інтеграції сенсорної інформації вважаються предикторами важливих результатів на заняттях, впливають на процес сну, розвитку мозку, гри, поведінки в цілому (Pfeiffer, May-Besson, \& Bodison, 2017).

У вітчизняній науці сенсорний розвиток дітей без патології вивчали Давидчук, Лішван, Парамонова; з порушеннями розвитку - Мінаєва, Обухова. Сенсорна депривація досліджувалася такими науковцями: Бєлова, Каліжнюк, Лєвченко, Мастюкова, Сімонова, Шамарін. Вплив сенсорної депривації на формування пізнавальних процесів досліджували Іпполитова, Кіріченко, Коноваленко (Вакуленко, 2018). Вітчизняні дослідження сенсорних процесів у дітей, зокрема дітей з порушеннями аутистичного спектра, залишаються актуальними, існує необхідність у розробці вітчизняного та адаптації зарубіжного діагностичного інструментарію для оцінки наявності та вираженості таких порушень.

Мета статті - аналіз методики Сенсомоторний батьківський опитувальник (Sensorimotor History Questionnaire for Preschoolers), опис iï адаптації, апробації та стандартизації на вітчизняній вибірці дітей дошкільного, молодшого шкільного та підліткового віку з розладами аутистичного спектру та без таких порушень (нормотипових).

Виклад основного матеріалу дослідження. Автором опитувальника є ерготерапевт BalzerMartin. Опитувальник розроблювався автором з метою скринінгового виявлення сенсорних порушень у дітей дошкільного віку (Balzer-Martin \& DeGangi 2000); (Kranowitz, 2005; 2008); (Balzer-Martin, 2008). Він складається з 17 питань, оцінка фіксується твердженням «так/ні». При наявності більше 3 позитивних відповідей рекомендується комплексне цілеспрямоване обстеження (Садовская, 2011).

3 метою створення адекватного психодіагностичного інтрументарію для дослідження особливостей сенсорної сфери дітей як нормотипових, так і з розладами аутистичного спектра було здійснено адаптацію методики Сенсомоторний батьківський опитувальник на вибірці українських дітей. Хоча опитувальник орієнтований на дошкільний вік, нами було здійснено спробу розширити іiі репрезентацію. На початковому етапі адаптації методики були перекладені інструкція i твердження методики із мова оригіналу (англійської) на українську мову із залученням професійного перекладача. Адаптований варіант пройшов асиметричний переклад, який дозволив зберегти смислове навантаження тверджень і дотримання вимог чіткості та однозначності формулювань (Бурлачук, 2008). Надалі було здійснено зворотній переклад на мову оригіналу задля перевірки еквівалентності адаптованого перекладу та були внесені певні корективи в україномовну версію методики. Для перевірки психометричних характеристик 
методики Сенсомоторний батьківський опитувальник було здійснено визначення показників надійності та валідності опитувальника.

У адаптації методики взяли участь 506 дітей (293 нормотипових дітей, з них 147 хлопчиків та 146 дівчаток від 3 до 16 років; 213 дітей з розладами аутистичного спектра, з них 158 хлопчиків та 55 дівчаток від 3 до 16 років). Були виділені 6 груп дітей за віком: дошкільний вік нормотипові діти (3-5 років; 149 дітей, з них 77 хлопчиків та 72 дівчинки); дошкільний вік - діти 3 розладами аутистичного спектра (3-5 років; 70 дітей, 53 хлопчики та 17 дівчаток); молодший шкільний вік - нормотипові діти (6-10 років; 96 дітей, 53 хлопчики та 43 дівчаток); молодший шкільний вік - діти з розладами аутистичного спектра (6-10 років; 99 дітей, 69 хлопчиків та 30 дівчаток); підлітковий вік - нормотипові діти (11-16 років; 48 дітей, 17 хлопців та 31 дівчина); підлітковий вік - діти з розладами аутистичного спектра (11-16 років; 44 дитини, 36 хлопців та 8 дівчат). Для підрахунку балів використовувалася програмне забезпечення Excel 2016, для перевірки психометричних характеристик методики статистична програма IBM SPSS Statistics 23.

Задля перевірки надійності адаптування Сенсомоторного батьківського опитувальника був проведений аналіз внутрішньої узгодженості тверджень методики. Для цієї мети використовувався статистичний показник Альфа Кронбаха. Згідно даних сучасної статистики, методика характеризується достатньою надійністю при розташуванні коефіцієнта Альфа Кронбаха у межах від 0,7 до 0,9. Таке розташування критерію вказує, що отримані значення є близькими до показників, що вимірюються (Бурлачук, 2008). Загальний показник Альфа Кронбаха для адаптованої нами методики склав 0,99, що свідчить про відміннний показник надійності щодо внутрішньої узгодженості тверджень (див. таб. 1).

Таблиия 1.

Загальна статистика внутрішньої узгодженості тверджень

\begin{tabular}{|c|c|c|}
\hline Альфа Кронбаха & N досліджуваних & N елементів \\
\hline 0,99 & 506 & 17 \\
\hline
\end{tabular}

Нами окремо було вираховано показник Альфа Кронбаха для групи нормотипових дітей, що склав 0,974 та для групи дітей з розладами аутистичного спектра, що становить 0,989 (див. таб. 2), що показує відмінний показник надійності щодо внутрішньої узгодженості тверджень методики.

Таблиия 2.

\section{Показники внутрішньої узгодженості}

\begin{tabular}{|c|c|c|c|c|c|}
\hline \multicolumn{3}{|c|}{$\begin{array}{c}\text { Статистика внутрішньої узгодженості для } \\
\text { групи нормотипових дітей }\end{array}$} & \multicolumn{3}{|c|}{$\begin{array}{c}\text { Статистика внутрішньої узгодженості } \\
\text { для групи дітей з РАС } \\
\text { (розладами аутистичного спектра) }\end{array}$} \\
\hline $\begin{array}{l}\text { Альфа } \\
\text { Кронбаха }\end{array}$ & $\begin{array}{c}\mathrm{N} \\
\text { досліджува- } \\
\text { них } \\
\end{array}$ & $\mathrm{N}$ елементів & $\begin{array}{l}\text { Альфа } \\
\text { Кронбаха }\end{array}$ & $\begin{array}{c}\mathrm{N} \\
\text { досліджува- } \\
\text { Них } \\
\end{array}$ & $\mathrm{N}$ елементів \\
\hline 0,974 & 293 & 17 & 0,989 & 213 & 17 \\
\hline
\end{tabular}

Задля визначення ще одного показника надійності адаптованої нами методики було використано статистичний аналіз ретестової надійності, що показує стійкість результатів дослідження у часі (Бурлачук, 2008). Для перевірки ретестової надійності було проведено повторне дослідження через 1,5 місяця після первинного тестування. Вибіркою ретесту стали 50 нормотипових дітей та 50 дітей 3 розладами аутистичного спектра, які повторно проходили дослідження. Після проведення ретесту був здійснений кореляційний аналіз результатів до і після за критерієм Пірсона (з часовим інтервалом 1,5 місяця). Результати кореляційного аналізу первинного та повторного дослідження свідчать про стійкість результатів адаптованої методики після повторного тестування. Коефіцієнт кореляції Пірсона становить 0,968 для вибірки 
нормотипових дітей (див. таб. 3) та 0,913 для вибірки дітей з розладами аутистичного спектра (див. таб. 4).

Результати ретестової надійності на вибірці нормотипових дітей

\begin{tabular}{|l|c|c|c|}
\hline $\begin{array}{c}\text { Результати аналізу ретестової надійності на } \\
\text { вибірці нормотипових дітей }\end{array}$ & $\begin{array}{c}\text { Первинне } \\
\text { тестування }\end{array}$ & $\begin{array}{c}\text { Повторне } \\
\text { тестування }\end{array}$ \\
\hline \multirow{2}{*}{$\begin{array}{l}\text { первинне } \\
\text { тестування }\end{array}$} & Кореляція Пірсона & 1 &, $968^{* *}$ \\
\cline { 2 - 4 } & Знач. (двостороння) & &, 000 \\
\hline \multirow{2}{*}{$\begin{array}{l}\text { повторне } \\
\text { тестування }\end{array}$} & $\mathrm{N}$ & 50 & 50 \\
\cline { 2 - 4 } & Кореляція Пірсона &, $968^{* *}$ & 1 \\
\cline { 2 - 4 } & Знач. (двостороння) &, 000 & 50 \\
\hline
\end{tabular}

**. Кореляція має значення на рівні 0,01 (двостороння).

Таблицяя 4.

Результати ретестової надійності на вибірці дітей з РАС (розладами аутистичного спектра)

\begin{tabular}{|l|c|c|c|}
\hline \multirow{2}{*}{$\begin{array}{l}\text { Результати аналізу ретестової надійності на } \\
\text { вибірці дітей з РАС }\end{array}$} & $\begin{array}{c}\text { Первинне } \\
\text { тестування }\end{array}$ & $\begin{array}{c}\text { Повторне } \\
\text { тестування }\end{array}$ \\
\hline \multirow{2}{*}{$\begin{array}{l}\text { первинне } \\
\text { тестування }\end{array}$} & Кореляція Пірсона & 1 &, $913^{* *}$ \\
\cline { 2 - 4 } & Знач. (двостороння) & &, 000 \\
\cline { 2 - 4 } & $\mathrm{N}$ & 50 & 50 \\
\hline \multirow{2}{*}{$\begin{array}{l}\text { повторне } \\
\text { тестування }\end{array}$} & Кореляція Пірсона &, $913^{* *}$ & 1 \\
\cline { 2 - 4 } & Знач. (двостороння) &, 000 & 50 \\
\cline { 2 - 4 } & $\mathrm{N}$ & 50 & \\
\hline
\end{tabular}

**. Кореляція має значення на рівні 0,01 (двостороння).

3 метою визначення варіативності відповідей та диференціювання за рівнем вираженості досліджуваної ознаки був використаний аналіз частотних розподілів по групах по адаптованій методиці за загальним показником, за показником у групі дітей з розладами аутистичного спектра та у групі нормотипових дітей загалом (див. табл. 5).

Таблиия 5.

Аналіз частотних розподілів за загальними показниками вибірок

\begin{tabular}{|c|c|c|c|}
\hline $\begin{array}{c}\text { Частотні розподіли } \\
\text { (процентилі) }\end{array}$ & $\begin{array}{c}\text { Загальний показник } \\
\text { усіх дітей } \\
\text { (N = 506) }\end{array}$ & $\begin{array}{c}\text { Діти 3 PAC } \\
(\mathbf{N}=\mathbf{2 1 3})\end{array}$ & $\begin{array}{c}\text { Нормотипові діти } \\
\text { (N = 293) }\end{array}$ \\
\hline 10 & 1 & 5 & 0 \\
\hline 20 & 2 & 6 & 2 \\
\hline 30 & 3 & 6 & 2 \\
\hline 40 & 4 & 7 & 4 \\
\hline 50 & 5 & 8 & 4 \\
\hline 60 & 6 & 9 & 6 \\
\hline 70 & 7 & 9 & 7 \\
\hline 80 & 9 & 10 & 2 \\
\hline 90 & 10 & 11 & \\
\hline
\end{tabular}

Додатково був здійснений аналіз частотних розподілів за віковими групами: дошкільний вік - нормотипові діти (3-5 років); дошкільний вік - діти з розладами аутистичного спектра (3-5

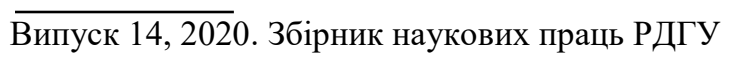


років); молодший шкільний вік - нормотипові діти (6-10 років); молодший шкільний вік-діти 3 розладами аутистичного спектра (6-10 років); підлітковий вік-нормотипові діти (11-16 років); підлітковий вік- діти з розладами аутистичного спектра (11-16 років) (див. табл. 6).

Табличя 6.

\section{Аналіз частотних розподілів за віковими групами}

\begin{tabular}{|c|c|c|c|c|c|c|}
\hline \multirow{2}{*}{$\begin{array}{c}\text { Процентильні } \\
\text { показники }\end{array}$} & \multicolumn{3}{|c|}{ Показники частотних розподілів за віковими підгрупами } \\
\cline { 2 - 7 } & \multicolumn{2}{|c|}{$3-5$ p. } & \multicolumn{2}{c|}{ 6-10 p. } & \multicolumn{2}{c|}{$11-16$ p. } \\
\cline { 2 - 7 } & $\begin{array}{c}\text { PAC } \\
(\mathrm{N}=70)\end{array}$ & $\begin{array}{c}\text { Hopмa } \\
(\mathrm{N}=149)\end{array}$ & $\begin{array}{c}\text { PAC } \\
(\mathrm{N}=99)\end{array}$ & $\begin{array}{c}\text { Hopмa } \\
(\mathrm{N}=96)\end{array}$ & $\begin{array}{c}\text { PAC } \\
(\mathrm{N}=44)\end{array}$ & $\begin{array}{c}\text { Норма } \\
(\mathrm{N}=48)\end{array}$ \\
\hline 10 & 4 & 0 & 5 & 0 & 6 & 0 \\
\hline 20 & 5 & 1 & 6 & 1 & 6 & 1 \\
\hline 30 & 6 & 2 & 6 & 2 & 7 & 1,7 \\
\hline 40 & 7 & 2 & 7 & 3 & 8 & 2 \\
\hline 50 & 8 & 3 & 8 & 3 & 8 & 2 \\
\hline 60 & 9 & 4 & 9 & 4 & 9 & 3 \\
\hline 70 & 9 & 5 & 10 & 4 & 9 & 4 \\
\hline 80 & 9 & 6 & 10 & 5 & 10 & 5 \\
\hline 90 & 10 & 8 & 11 & 6 & 11,5 & 6 \\
\hline
\end{tabular}

Вищезазначені дані вказують на високу варіативність питань адаптованої методики, що дозволяє отримувати значущі показники диференціації дітей та підлітків як нормотипових, так і 3 розладами аутистичного спектра за рівнями вираженості сенсорних порушень за віком. Для встановлення якості адаптованої нами методики був проведений аналіз іï валідності (як відповідності між рівнем вираженості досліджуваної ознаки та методом ії діагностики) (Бурлачук, 2008). Для адаптованого варіанту методики було проаналізовано очевидну та критеріальну валідність.

Визначаючи очевидну валідність, респондентам (батькам дітей, які брали участь у дослідженні) було запропоновано відповісти на відкрите запитання: «Як ви гадаєте, що вимірює ця методика?». За результатами статистичного аналізу відповідей, $67 \%$ респондентів вірно визначили мету діагностичного інструментарію («досліджує відчуття», «досліджує сенсорику», «досліджує проблеми чутливості дитини», «чутливість», «тілесні проблеми дитини», «психомоторний розвиток»); 22\% респондентів були близькими до вірної відповіді («досліджує проблеми розвитку дитини», «чи правильно розвивається дитина», «проблеми зі здоров'ям у дитини»); $11 \%$ - утрималися від відповіді. Таким чином, адаптована нами методика показує достатній рівень очевидної валідності.

Для визначення критеріальної (зовнішньої) валідності батькам було запропоновано відповісти на закрите питання: «Чи має ваша дитина проблеми 3 інтеграцією сенсорної інформації?» (зміст запитання уточнювався). Після цього випадковим чином було відібрано 50 нормотипових дітей, батьки яких відповіли «так» та 50 дітей, батьки яких відповіли «ні». Також було відібрано 50 дітей з розладами аутистичного спектра, батьки яких відповіли «так» та 50 дітей, відповідь батьків яких була «ні».

Було порівнено загальну вибірку відповідей батьків з аутизмом та нормотипових (див. рис 1), вибірку відповідей батьків нормотипових дітей (див. рис. 2) та вибірку відповідей батьків дітей 3 розладами аутистичного спектра (див. рис. 3) за допомогою критерію Манна-Уітні. За усіма вибірками було отримано рівень значущості $(0,05)$, який підтверджує критеріальну (зовнішнью) валідність. 


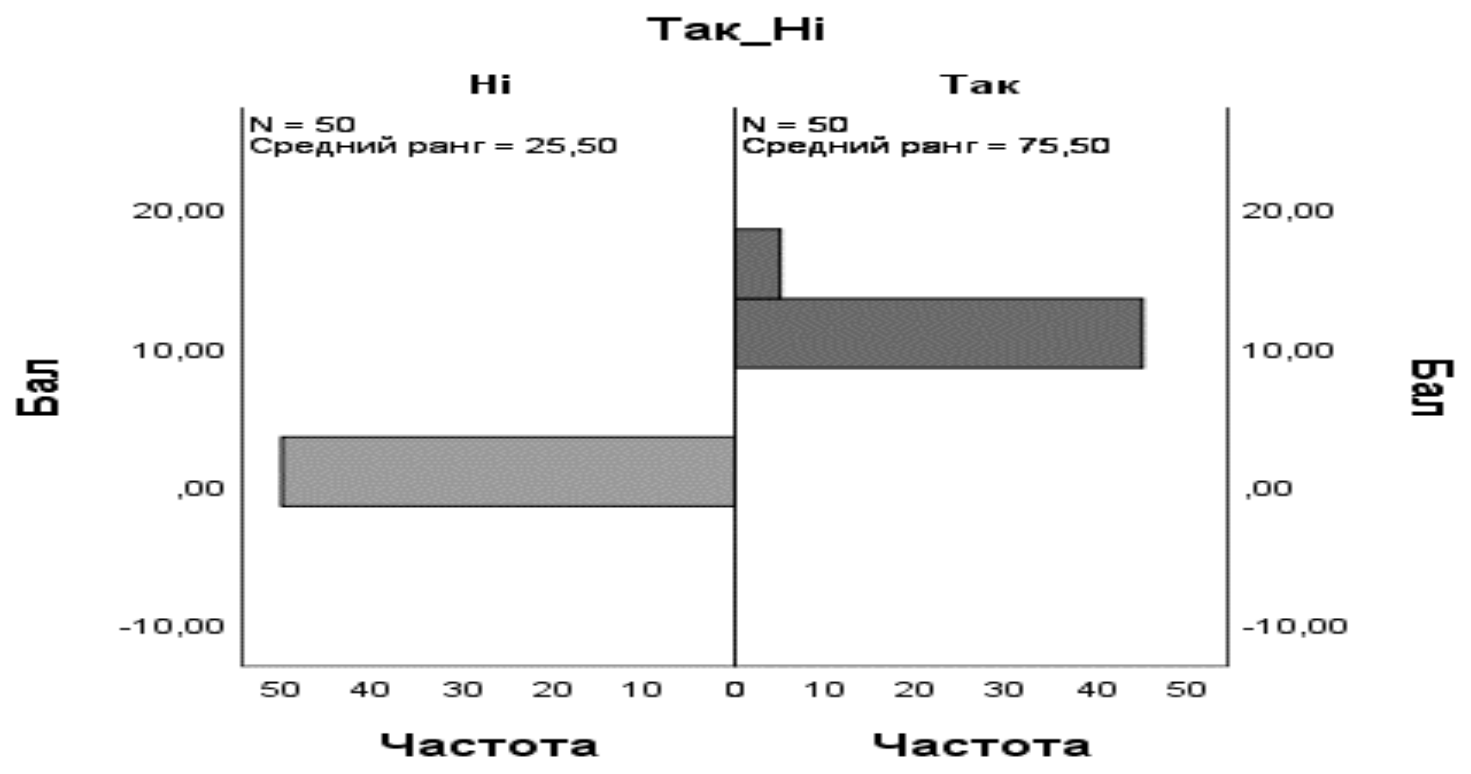

Рис. 1. Зовнішня (критеріальна) валідність загальної вибірки

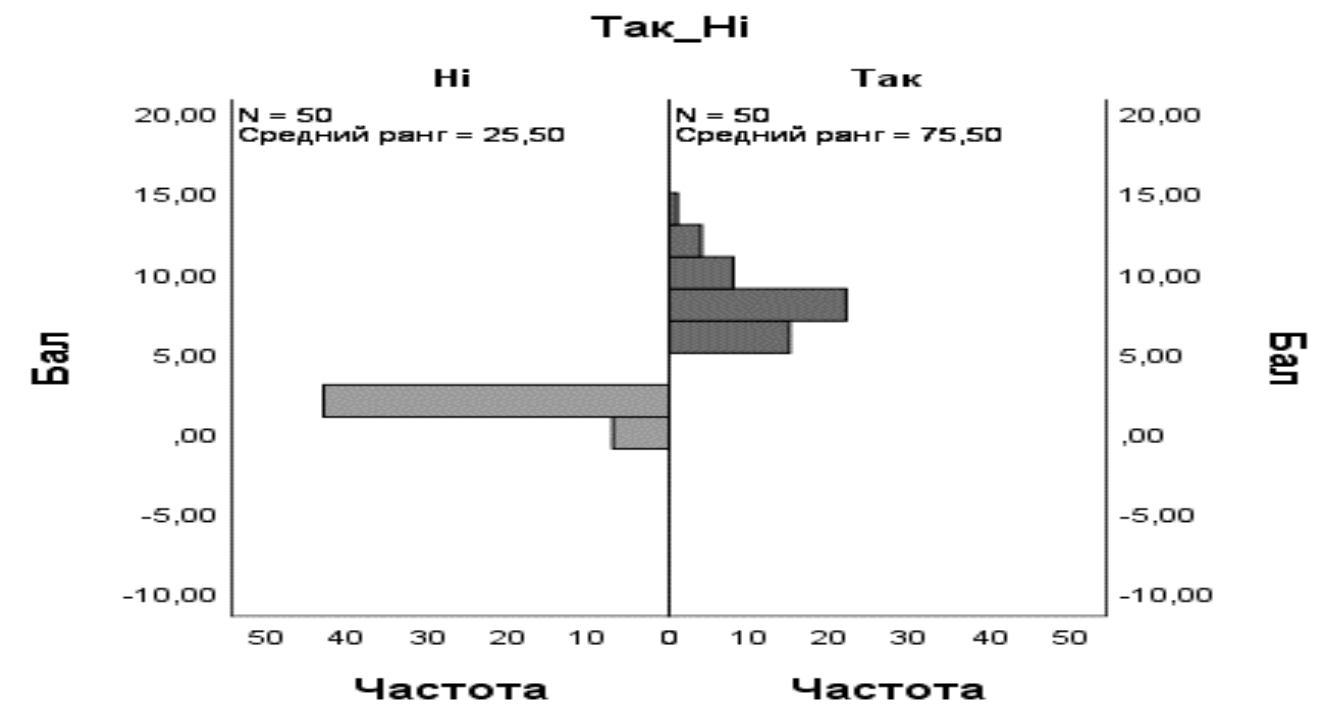

Рис. 2. Зовнішня (критеріальна) валідність батьків нормотипової вибірки

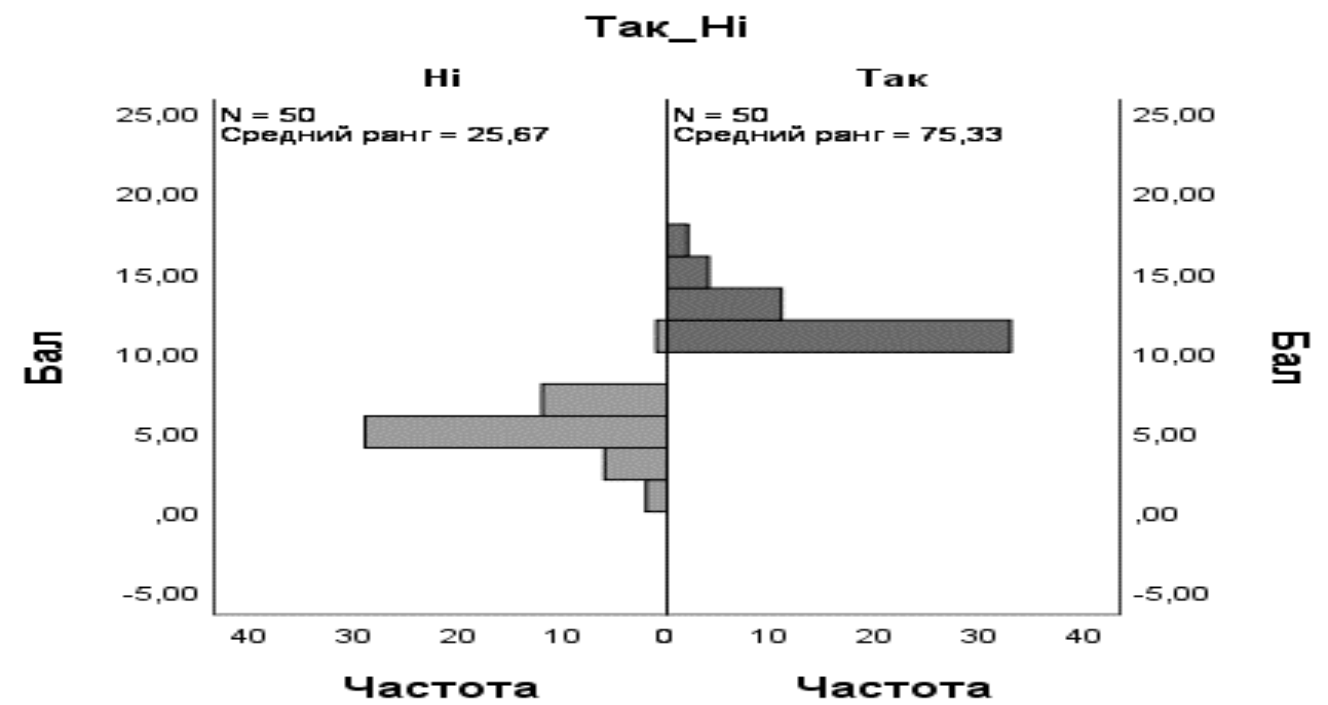

Рис. 3. Зовнішня (критеріальна) валідність вибірки батьків дітей з РАС 
Задля визначення розбіжностей між результатами групи нормотипових дітей та дітей 3 аутизмом, було здійснено їх співставлення. Ми порівняли загальну вибірку дітей з РАС та нормотипових дітей (див. рис. 4), дошкільного віку (див. рис. 5), молодшого шкільного віку (див. рис. 6) та підліткового віку (див. рис. 7). Для цього ми використали статистичний критерій МаннаУітні. Усі вибірки показали рівень значущості 0,05 , що вказує на значні розбіжності між вибірками.

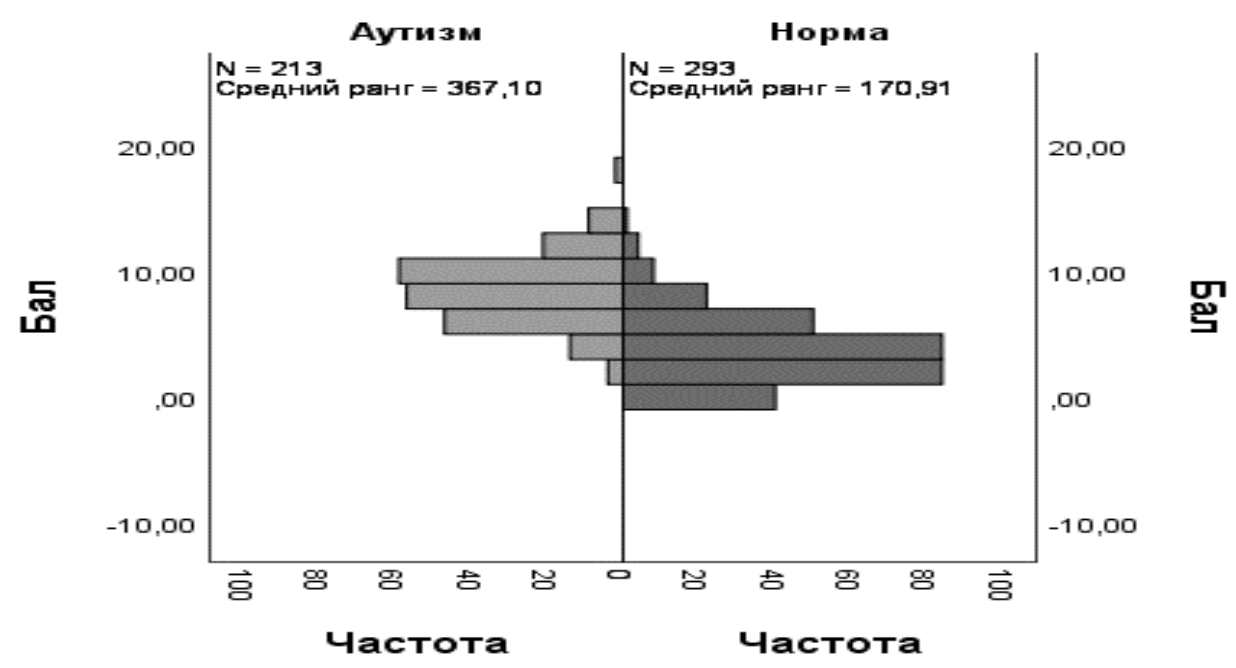

Рис. 4. Порівняння загальної вибірки дітей з РАС та нормотипових дітей

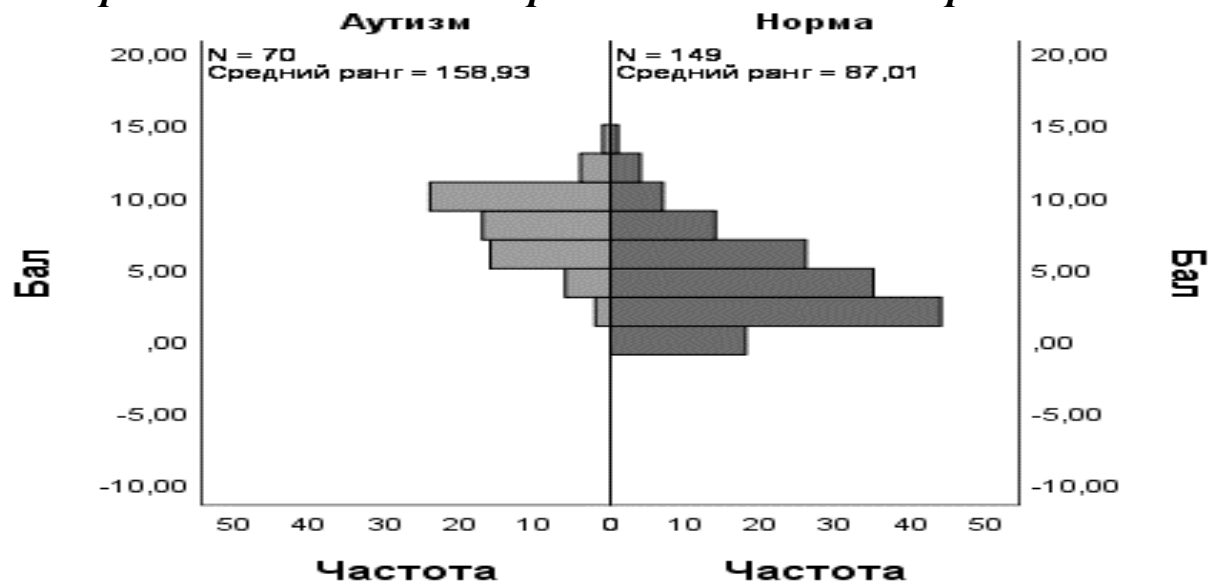

Рис. 5. Порівняння вибірки дітей з РАС та нормотипових дітей доикільного віку

(3-5 років)

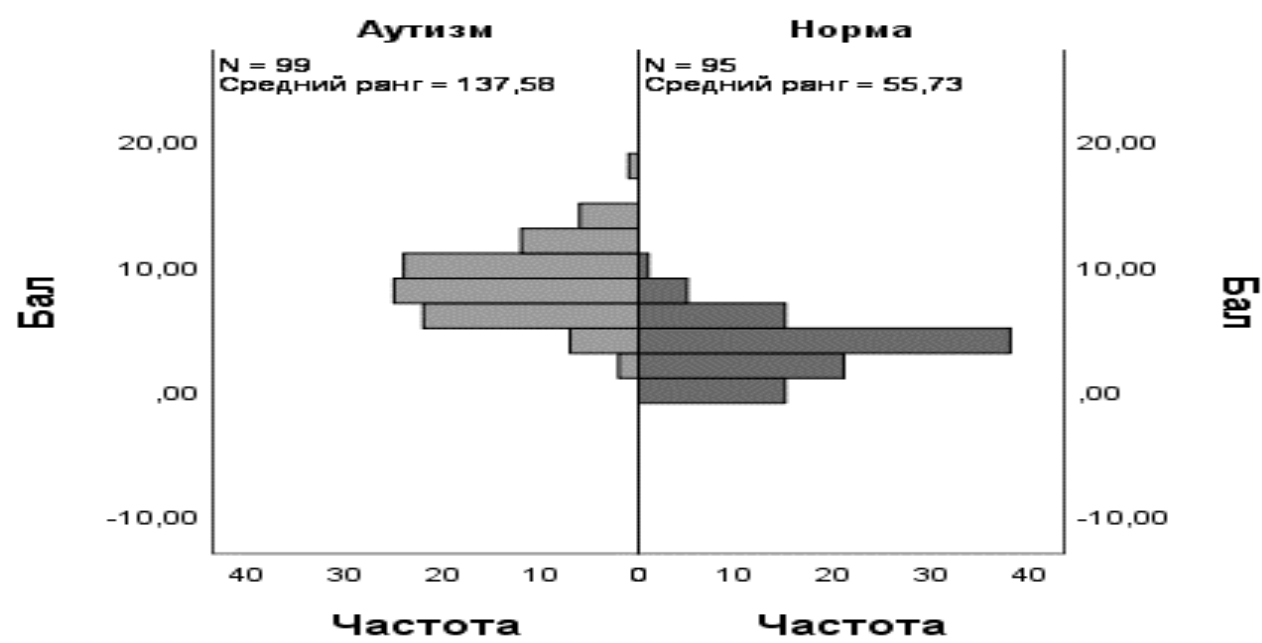

Рис. 6. Порівняння вибірки дітей з РАС та нормотипових дітей молодиого икільного віку (6-10 років) 


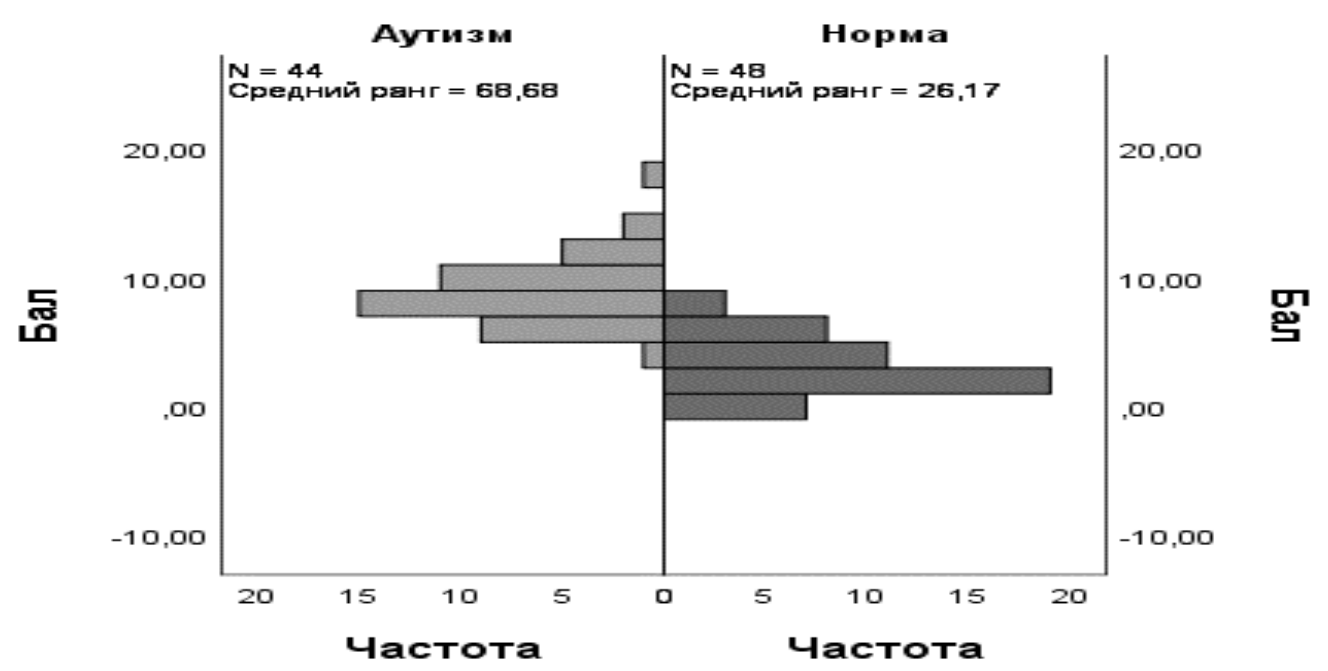

Рис. 7. Порівняння вибірки дітей з РАС та нормотипових дітей підліткового віку (11-16 років)

Останнім етапом в адаптації методики була стандартизація процедури та інтерпретації результатів дослідження. Кінцевий варіант адаптованої методики складається із 17 прямих тверджень, на які потрібно відповідати «так» чи «ні». Згідно з отриманими даними щодо розподілу показників за методикою «Сенсомоторний батьківський опитувальник» було прийнято рішення про розподіл балів таким чином: 0-3 бали - проблем немає або вони незначні; 4-6 балів вказують на наявність проблем середньої вираженості; 7-10 - яскраво виражені проблеми; 11 і вище серйозні проблеми сенсомоторної сфери.

Висновки та перспективи подальших розвідок. Вивчення порушень сенсорної сфери i пов'язаних з ними етіологічних факторів у нормотипових дітей є затребуваними, а при РАС все ще перебувають у стані первинної розробки і потребують подальших досліджень. У зв'язку з цим існує необхідність у розробці вітчизняного та адаптації зарубіжного діагностичного інструментарію для оцінки наявності та вираженості сенсорних порушень у дітей. Згідно посталених завдань, нами було проаналізовано оригінальну методику, переведено її на українську мову, успішно адаптовано, апробовано та стандартизовано на вибірці українських нормотипових дітей та дітей з розладами аутистичного спектра, що доведено високим рівнем психометричних показників. Наступним завданням ми вбачаємо визначення етіологічних та супутніх факторів у порушеннях обробки та інтеграції сенсорної інформації у дітей, зокрема у дітей з розладами аутистичного спектра.

\section{СПИСОК ПОСИЛАНЬ}

Бурлачук, Л. Ф. (2008). Психодиагностика: Учебник для вузов. Санкт-Петербург: Питер.

Вакуленко, Ю. В. (2018). Сенсорна дисфункція та ії корекція у дітей з розладами аутичного спектру. Науковий вісник Херсонського державного університету. Серія: Психологічні науки, 4, 277-281.

Садовская, Ю. Е. (2011). Нарушение сенсорной обработки и диспраксии у детей дошкольного возраста. (Дис. д-ра мед. наук). Российский государственный медицинский университет федерального агенства по здравохранению и социальному развитию, Москва.

Скрипник, Т. В. (2016). Сенсорна інтеграція як підгрунтя цілісного розвитку дітей з аутизмом. Особлива дитина: навчання і виховання, 4, 24-31.

Balzer-Martin, L. A. (2008). In C. S. Kranowitz (Ed.). The Out-of-Sync Child (p. 322). A skylight press book.

Celik, H. I., Elbasan, B., Gucuyener, K., Kayihan, H., \& Huri, M. (2018). Investigation of the relationship between sensory processing and motor development in preterm infants. American Journal of Occupational Therapy 72(1). doi.org/10.5014/ajot.2018.026260. 
DeGangi, G., \& Balzer-Martin, L. A. (2000). Sensorimotor history questionnaire for preschoolers. In G. DeGangi (Ed.). Pediatric disorders of regulation in affect and behavior - a therapist's guide to assessment and treatment (pp. 361-365). San Diego: Academic Press.

Dean, E. E., Little, L., Tomchek, S., \& Dunn, W. (2018). Sensory processing in the general population: Adaptability, resiliency, and challenging behavior. American Journal of Occupational Therapy, 72, 1-8. doi:10.5014/ajot.2018.019919.

Foitzik, K., \& Brown, T. (2018). Relationship between sensory processing and sleep in typically developing children. American Journal of Occupational Therapy, 72(1). doi:10.5014/ajot.2018.027524.

Jorquera-Cabrera, S., Romero-Ayuso, D., Rodriguez-Gil, G., \& Triviño-Juárez, J.-M. (2017). Assessment of Sensory Processing Characteristics in Children between 3 and 11 Years Old: A Systematic Review. Frontiers in Pediatrics, 5. doi:10.3389/fped.2017.00057.

Jussila, K., Junttila, M., Kielinen, M., Ebeling, H., Joskitt, L., Moilanen, I., \& Mattila, M.-L. (2019). Sensory Abnormality and Quantitative Autism Traits in Children With and Without Autism Spectrum Disorder in an Epidemiological Population. Journal of Autism and Developmental Disorders. doi:10.1007/s10803-019-04237-0.

Kojovic, Ben Hadid, Franchini, \& Schaer. (2019). Sensory Processing Issues and Their Association with Social Difficulties in Children with Autism Spectrum Disorders. Journal of Clinical Medicine, 8(10), 1508. doi:10.3390/jcm8101508.

Pastor-Cerezuela, G., Fernández-Andrés, M.-I., Sanz-Cervera, P., \& Marín-Suelves, D. (2020). The impact of sensory processing on executive and cognitive functions in children with autism spectrum disorder in the school context. Research in Developmental Disabilities, 96. doi:10.1016/j.ridd.2019.103540.

Pfeiffer, B. A., Koenig, K., Kinnealey, M., Sheppard, M., \& Henderson, L. (2011). Effectiveness of sensory integration interventions in children with autism spectrum disorders: A pilot study. American Journal of Occupational Therapy, 65(1), 76-85. doi:10. 5014/ajot.2011.09205.

Pfeiffer, B., May-Besson, T., \& Bodison, S. (2017). State of the science of sensory integration research with children and youth. American Journal of Occupational Therapy, 72. doi:10.5014/ajot.2018.721003.

Pickard, H., Hirsch, C., Simonoff, E., \& Happé, F. (2020). Exploring the cognitive, emotional and sensory correlates of social anxiety in autistic and neurotypical adolescents. Journal of Child Psychology and Psychiatry. doi:10.1111/jcpp.13214.

Roberts, T., Stagnitti, K., Brown, T. \& Bhopti, A. (2017). Relationship between sensory processing and pretend play in typically developing children. American Journal of Occupational Therapy, 72(1). doi:10.5014/ajot.2018.027623.

Ueno, Y., Takahashi, A., \& Oshio, A. (2019). Relationship between sensory-processing sensitivity and age in a large cross-sectional Japanese sample. Heliyon, 5(10). doi:10.1016/j.heliyon.2019.e02508.

\section{REFERENCES}

Burlachuk, L. F. (2008). Psihodiagnostika: Uchebnik dlja vuzov [Psychodiagnostiks: a textbookfor high schools]. Sankt-Peterburg : Piter. [in Russian].

Vakulenko, Yu. (2018). Sensorna dy`sfunkciya ta yiyi korekciya u ditej z rozladamy`auty`chnogo spektru [Sensory dysfunction and its correction in children with autism spectrum disorder]. Naukovy`j visny`k Xersons`kogo derzhavnogo universy`tetu. Seriya: Psy`xologichni nauky`, 4, 277-281. [in Ukrainian].

Sadovskaja, Ju. E. (2011). Narushenie sensornoj obrabotki i dispraksii u detej doshkol'nogo vozrasta [Impairment of sensory processing and dyspraxia in preschool children]. (dis. d-ra med. nauk). Rossijskij gosudarstvennyj medicinskij univversitet federal'nogo agenstva po zdravohraneniju i social'nomu razvitiju. Moskva. [in Russian].

Skry`pny`k, T. V. (2016). Sensorna integraciya yak pidgruntya cilisnogo rozvy`tku ditej z auty`zmom [Sensory integration as a basis for the holistic development of children with autism]. Osobly va dy`ty`na: navchannya i vy`xovannya, 4, 24-31. [in Ukrainian]. 
Balzer-Martin, L. A. (2008). In: C. S. Kranowitz (Ed.). The Out-of-Sync Child. ( p. 322). A skylight press book. [in English].

Celik, H. I., Elbasan, B., Gucuyener, K., Kayihan, H., \& Huri, M. (2018). Investigation of the relationship between sensory processing and motor development in preterm infants. American Journal of Occupational Therapy 72(1). doi.org/10.5014/ajot.2018.026260. [in English].

DeGangi, G., \& Balzer-Martin, L. A. (2000). Sensorimotor history questionnaire for preschoolers. In G. DeGangi, (Ed.), Pediatric disorders of regulation in affect and behavior - a therapist's guide to assessment and treatment (pp. 361-365). San Diego: Academic Press. [in English].

Dean, E. E., Little, L., Tomchek, S., \& Dunn, W. (2018). Sensory processing in the general population: Adaptability, resiliency, and challenging behavior. American Journal of Occupational Therapy, 72, 1-8. doi:10.5014/ajot.2018.019919. [in English].

Foitzik, K., \& Brown, T. (2018). Relationship between sensory processing and sleep in typically developing children. American Journal of Occupational Therapy, 72(1). doi:10.5014/ajot.2018.027524. [in English].

Jorquera-Cabrera, S., Romero-Ayuso, D., Rodriguez-Gil, G., \& Triviño-Juárez, J.-M. (2017). Assessment of Sensory Processing Characteristics in Children between 3 and 11 Years Old: A Systematic Review. Frontiers in Pediatrics, 5. doi:10.3389/fped.2017.00057. [in English].

Jussila, K., Junttila, M., Kielinen, M., Ebeling, H., Joskitt, L., Moilanen, I., \& Mattila, M.-L. (2019). Sensory Abnormality and Quantitative Autism Traits in Children With and Without Autism Spectrum Disorder in an Epidemiological Population. Journal of Autism and Developmental Disorders. doi:10.1007/s10803-019-04237-0. [in English].

Kojovic, Ben Hadid, Franchini, \& Schaer. (2019). Sensory Processing Issues and Their Association with Social Difficulties in Children with Autism Spectrum Disorders. Journal of Clinical Medicine, 8(10), 1508. doi:10.3390/jcm8101508. [in English].

Pastor-Cerezuela, G., Fernández-Andrés, M.-I., Sanz-Cervera, P., \& Marín-Suelves, D. (2020). The impact of sensory processing on executive and cognitive functions in children with autism spectrum disorder in the school context. Research in Developmental Disabilities, 96. doi:10.1016/j.ridd.2019.103540. [in English].

Pfeiffer, B. A., Koenig, K., Kinnealey, M., Sheppard, M., \& Henderson, L. (2011). Effectiveness of sensory integration interventions in children with autism spectrum disorders: A pilot study. American Journal of Occupational Therapy, 65(1), 76-85. doi:10. 5014/ajot.2011.09205. [in English].

Pfeiffer, B., May-Besson, T., \& Bodison, S. (2017). State of the science of sensory integration research with children and youth. American Journal of Occupational Therapy, 72. doi:10.5014/ajot.2018.721003. [in English].

Pickard, H., Hirsch, C., Simonoff, E., \& Happé, F. (2020). Exploring the cognitive, emotional and sensory correlates of social anxiety in autistic and neurotypical adolescents. Journal of Child Psychology and Psychiatry. doi:10.1111/jcpp.13214. [in English].

Roberts, T., Stagnitti, K., Brown, T. \& Bhopti, A. (2017). Relationship between sensory processing and pretend play in typically developing children. American Journal of Occupational Therapy, 72(1). doi:10.5014/ajot.2018.027623. [in English].

Ueno, Y., Takahashi, A., \& Oshio, A. (2019). Relationship between sensory-processing sensitivity and age in a large cross-sectional Japanese sample. Heliyon, 5(10). doi:10.1016/j.heliyon. 2019.e02508. [in English]. 


\title{
SENSOMOTOR QUESTIONNAIRE FOR PARENTS: ADAPTATION ON UKRAINIAN SAMPLE OF TYPICAL CHILDREN AND CHILDREN WITH AUTISM SPECTRUM DISORDER
}

\author{
Yuliia Vakulenko \\ PHD student of the Department of Psychodiagnostics \\ and Clinical Psychology Faculty of Psychology \\ Taras Shevchenko National University of Kyiv \\ ORCID ID: 0000-0003-2354-4169 \\ DOI https://doi.org/10.35619/prap_rv.vi14.149
}

\begin{abstract}
The article described and analysed the Sensorimotor History Questionnaire for Preschoolers. The problem of impaired processing and integration of sensory information in typical children and children with autism spectrum disorders is considered. Attention is drawn to the need for research of features of the sensory sphere and its violations in typical children and children with ASD in the domestic sample. The results of adaptation and validation of the questionnaire on the sample of Ukrainian children are presented. To calculate the points, the Excel 2016 was used, and to check the psychometric characteristics of the questionnaire, the statistical program IBM SPSS Statistics 23 was used.
\end{abstract}

The questionnaire was translated into the Ukrainian language from the original language (English) with the assistance of a professional interpreter. An adapted version has passed an asymmetrical translation, which helped to keep the meaning of the claims and compliance with the requirements of clarity and certainty language. In the adaptation of the questionnaire took part 506 children (293 typical children (147 boys and 146 girls from 3 to 16 years; 213 children with autism spectrum disorders (158 boys and 55 girls from 3 to 16 years). Were allocated to 6 groups of children age - preschool age-typical children (3-5 years; 149 children, 77 boys and 72 girls); preschool age children with autism spectrum disorders (3-5 years; 70 children, 53 boys and 17 girls); younger school age-typical children (6-10 years; 96 children, 53 boys and 43 girls); younger school age-children with autism spectrum disorders (6-10 years; 99 children, 69 boys and 30 girls); adolescent typical children (11-16 years old; 48 children, 17 boys and 31 girls); adolescent children with autism spectrum disorders (11-16 years; 44 children, 36 boys and 8 girls). To check the psychometric characteristics of the questionnaire was carried out the determination of indicators of reliability (reliability as internal consistency and and reliability of repeated testing) and validity (apparent validity and criterion validity). Psychometric characteristics showed a high and sufficient level.

The procedure and interpretation of the study results were standardized. For this, the frequency distribution was calculated by the general indicator and additionally by age groups to determine the severity of sensory disturbances in children and adolescents. According to the results of frequency distribution, it was determined the overall distribution of scores, which gives the possibility to determine the presence and severity of the violations processing and integration of sensory information in children.

Key words: adaptation, autism spectrum disorder, feelings, reliability, sensory integration, sensory processes, sensory processing disorder, standardization, testing, validity. 